exertional rhinorrhoea inhalation of cold dry air elicited a mean threefold increase in symptom scores and a mean sixfold increase in histamine concentrations in lavage fluid, accompanied by significant increases of prostaglandin $D_{2}$, leukotrienes, tosyl-L-arginine methyl esterases, and kinins. ${ }^{12}$ No change in mediator concentrations were detected after a control inhalation of warm and moist air.' The release of inflammatory mediators from the nasal mucosa was associated with an increase in the osmolarity of the nasal secretions. ${ }^{3}$ The findings that nasal lavage with hyperosmolar solutions induces symptomatic rhinorrhoea, which was concomitant with increased concentrations of inflammatory mediators in nasal lavage fluid, support the view that cold dry air elicits release of mediators through a loca hyperosmolar stimulus to the nasal membrane. ${ }^{4}$ In vitro studies of basophils and mast cells of the lung have shown that an increase in the osmolarity of the surrounding medium is a potent stimulus for secretion of mediators. ${ }^{5.7}$ Thus mast cell degranulation due to changes in airway osmolarity may be important in the aetiology of exercise induced rhinorrhoea.

STEVE O'HICKEY

P CHRISTIE

TAK LEE

Department of Allergy and Allied Respiratory Disorders, Guy's Hospital,

London SE1 9RT

1 Togias AG, Naclerio RM, Proud D, et al. Nasal challenge with cold, dry air results in release of inflammatory mediators. f Clin Invest 1985;76:1375-81.

2 Togias AG, Naclerio RM, Peters SP, et al. Local generation of sulfidopeptide leukotrienes upon nasal provocation with cold, dry air. Am Reo Respir Dis 1986;133:1133-7.

Togias AG, Proud D, Lichtenstein LM et al. The osmolality of alas AG, Proud D, Lichtenstein LM, et $a l$. The osmolality of nasal secretions increases when inflamm Respir Dis 1988;137:625-9.

Silber G, Proud D, Marner J, et al. In vivo release of inflam matory mediators by hyperosmolar solutions. Am Rev Respir Dis 1988;137:606-12.

5 Banks JR, Kagey-Sobotka A, Lichtenstein LM. Spontaneous histamine release after exposure to hyperosmolar solution $\mathcal{f}$ Allergy Clin Immunol 1986;78:51-7.

6 Eggleston PA, Kagey-Sobotka A, Lichtenstein LM. A comparison of the osmotic activation of basophils and human lung mast cells. Am Rev Respir Dis 1987;135: 1043-8.

Findlay SR, Dvorak AM, Kagey-Sobotka A, Lichtenstein LM. Hyperosmolar triggering of histamine release from human basophils. F Clin Invest 1981;67:1604-13.

\section{Postperinatal mortality in a health district with a garrison town}

Dr Mala Rao and Ms Elizabeth Hoinville (10 September, $p$ 662) noted that the death rate in the children of soldiers was higher than that in the rest of the population in North East Essex health district. This was not adjusted for social class. Members of the armed forces and students are classified as "other" in the Registrar General's classification. When social class is taken into consideration the adjusted postperinatal mortality rate becomes rather better than that for England

Births in Essex Area Health Authority and perinatal and postnatal mortality per 1000 births in England and Wales during 1980 by social class

Social class

\begin{tabular}{|c|c|c|c|c|c|c|c|c|c|c|}
\hline & \multicolumn{9}{|c|}{ Social class } & \multirow[b]{3}{*}{ Total } \\
\hline & \multirow[b]{2}{*}{ I } & \multirow[b]{2}{*}{ II } & \multicolumn{3}{|c|}{ III } & \multirow[b]{2}{*}{ IV } & \multirow[b]{2}{*}{ V } & \multirow[b]{2}{*}{ Other } & \multirow[b]{2}{*}{ Illegitimate } & \\
\hline & & & $\mathrm{N}$ & $M$ & All & & & & & \\
\hline \multirow{4}{*}{$\begin{array}{l}\text { Births in Essex Area Health } \\
\text { Authority }(\%) \\
\text { Perinatal mortality per } 1000 \text { births } \\
\text { in England and Wales } \\
\text { Postnatal mortality per } 1000 \text { births } \\
\text { in England and Wales }\end{array}$} & $6 \cdot 4$ & $23 \cdot 8$ & & & \multirow[t]{4}{*}{$45 \cdot 4$} & $11 \cdot 4$ & $3 \cdot 3$ & 1.9 & $7 \cdot 7$ & 39063 \\
\hline & & & & & & & & & & \\
\hline & $9 \cdot 7$ & $11 \cdot 1$ & $11 \cdot 8$ & $13 \cdot 0$ & & $15 \cdot 0$ & $17 \cdot 0$ & $14 \cdot 9$ & 16.9 & $13 \cdot 3^{\star}$ \\
\hline & $3 \cdot 3$ & $3 \cdot 1$ & $3 \cdot 4$ & $3 \cdot 5$ & & $4 \cdot 8$ & $6 \cdot 2$ & $8 \cdot 1$ & 6.9 & $4 \cdot 3$ \\
\hline
\end{tabular}

*Perinatal mortality per 1000 births was 13.8 in North East Thames Regional Health Authority. region rather than the femoral head. We look forward to studying further such patients with magnetic resonance imaging. Though we accept that changes in vascularity may be involved in this condition, we were surprised that these authors do not accept the concept of a capsulitis of the hip, which has clearly been documented in the French studies.

Dr Anthony Coral has kindly alerted us to the work of Lequesne et al on idiopathic capsular constriction of the hip, which is likely to be part of the range of the condition frozen hip. Neither of our two patients who had arthrography showed any failure of filling of the normal recesses, but only $10 \mathrm{ml}$ of contrast material was injected. Although almost all of the reported cases of capsular constriction have a joint capacity less than this, we might have been able to show some reduction in capacity or minor filling abnormalities with a larger volume.

M D CHARD J R JENNER

Rheumatology Research Unit,

Addenbrooke's Hospital,

Cambridge CB2 2QQ

1 Ficat RP. Idiopathic bone necrosis of the femoral head. $f$ Bone foint Surg [Br] 1985;67:3-9.

\section{Ectopic pregnancy}

Professor John Newton (10 September, p 633) implies that, despite advances in the urinary measurement of human chorionic gonadotrophin, serum radioimmunoassay remains the standard assessment of this hormone in ectopic pregnancy. Much has been published since the references he quotes to cast doubt on this opinion.

The introduction of two site monoclonal antibodies against human chorionic gonadotrophin and immunoenzymatic methods has led to a new generation of urinary tests that reliably detect concentrations of human chorionic gonadotrophin down to $30 \mathrm{U} / 1$ (first international reference preparation) and, with modification, to $1 \mathrm{U} / 1$ within five minutes of the start of the assay. ${ }^{12}$ Moreover, many of these tests may be performed at the bedside by comparatively unskilled operators throughout the day without a specialised laboratory. ${ }^{3}$ These assays, therefore, theoretically offer a convenient and extremely reliable assessment of human chorionic gonadotrophin state.

I and others have shown that urine based assays for human chorionic gonadotrophin offer a diagnostic sensitivity and specificity at least as good as those of a serum radioimmunoassay in diagnosing ectopic pregnancy. ${ }^{45}$ Our initial predictive indices of nearly $100 \%{ }^{6}$ have been confirmed in much larger studies, ${ }^{45}$ and use of serum for qualitative or quantitative assessment of human chorionic gonadotrophin does not offer any advantage over the much simpler use of urine specimens. There is an extremely good case to be made for measuring urinary human chorionic gonadotrophin with a reliable immunoenzymatic method - for example, Tandem Icon (Hybridtech, San Diego)- which takes five minutes, followed by ultrasonography and a rapid semiquantitative progesterone assay. All this can be performed in under 60 minutes with an early decision to consider operative management.

R J NORMAN

Department of Obstetrics and Gynaecology, GPO Box 498,

Adelaide,

South Australia 5001

1 Buck RH, Norman RJ, Reddi K, Moodley J, Joubert SM Evaluation of various methods for urinary choriogonadotropin in early diagnosis of ectopic pregnancy. Clin Chem 1986;32. 879-83.

2 Buck RH, Joubert SM, Norman RJ. A bedside test for human chorionic gonadotropin as sensitive as serum radioimmunoassay. Clin Chem 1986;32:1596. 
3 Buck RH, Pather N, Moodley J, Joubert SM, Norman RJ Bedside application of an ultrasensitive test for $\mathrm{hCG}$ in patient with suspected ectopic pregnancy. Ann Clin Biochem 1987;24: 268-72.

4 Buck RH, Gihwala N, Rom L, Joubert SM, Norman RJ Detection of urinary human chorionic gonadotropin by rapid immunoconcentration method is the first-line test fo suspected ectopic pregnancy. Fertil Steril 1987;48:761-5.

5 Norman RJ, Buck RH, Rom L, Joubert SM. Blood or urine measurement of human chorionic gonadotropin for detection of ectopic pregnancy? A comparative study of quantitative and qualitative methods in both fluids. Obstet Gynecol 1988;71: 315-8.

6 Norman RJ, Reddi K, Kemp M, Joubert SM, Patel F. Sensitive urine tests and human chorionic gonadotrophin secreted during ectopic pregnancy. $B r$ Med $\mathcal{F}$ 1986;292:590-1.

\section{Fish oil and plasma fibrinogen}

Dr D P Mikhailidis and colleagues (3 September, p 615) suggest a possible relation between hypertriglyceridaemia and fibrinogen concentrations. They comment on the lack of appropriate triglyceride data in the paper by Dr Arne T Høstmark and others (16 July, p 180).

In 1980 an open study to observe the effects of $\omega$-3 marine triglycerides (Maxepa) on blood lipid concentrations and coagulation was instigated in this laboratory. The results of the first four years of study on data collected from 267 patients taking $10 \mathrm{ml} \omega-3$ marine triglycerides daily $(1.8 \mathrm{~g}$ eicosapentaenoic acid) suggested a significant and progressive decrease in plasma fibrinogen concentration (table I). None of the patients showed any tendency to excessive bleeding. Serum triglyceride concentrations were significantly reduced (table II) and correlated with our earlier findings. ${ }^{1}$ Over the same period, however, total cholesterol concentration was significantly reduced in subjects with raised baseline values and high density lipoprotein cholesterol concentration significantly increased.

The inverse relation between triglyceride and high density lipoprotein cholesterol concentrations is well known, but recent work has shown that fish

TABLE I-Fibrinogen concentrations $(\mathrm{g} / \mathrm{l})$ in patients before and after taking $\omega-3$ marine triglycerides

\begin{tabular}{lcccc}
\hline \multirow{2}{*}{$\begin{array}{l}\text { Time } \\
\text { (months) }\end{array}$} & $\begin{array}{c}\text { No of } \\
\text { patients }\end{array}$ & \multicolumn{2}{c}{ Mean fibrinogen } & $\begin{array}{c}\text { Patients } \\
\text { with }\end{array}$ \\
\cline { 5 - 5 } $\begin{array}{l}\text { Before } \omega-3 \\
\text { marine }\end{array}$ & & & & \\
triglycerides & 267 & 3.52 & 3.52 & \\
1 & 255 & 3.52 & 3.38 & $63^{\star \star}$ \\
3 & 234 & 3.52 & 3.32 & $63^{\star \star}$ \\
6 & 203 & 3.57 & 3.24 & $65^{\star \star}$ \\
12 & 171 & 3.61 & 3.35 & $60^{\star}$ \\
18 & 146 & 3.67 & 3.34 & $64^{\star \star}$ \\
24 & 126 & 3.70 & 3.22 & $73^{\star \star}$ \\
30 & 112 & 3.74 & 3.15 & $76^{\star \star}$ \\
36 & 97 & 3.78 & 2.97 & $91^{\star \star}$ \\
42 & 84 & 3.76 & 2.94 & $86^{\star \star}$ \\
48 & 65 & 3.78 & 2.90 & $94^{\star \star}$ \\
\hline
\end{tabular}

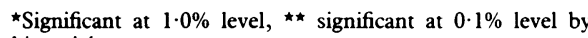
binomial test.

TABLE II - Total triglyceride concentrations (mmolll) in patients with raised baseline values before and after taking $\omega-3$ marine triglycerides

\begin{tabular}{|c|c|c|c|c|}
\hline \multirow{2}{*}{$\begin{array}{l}\text { Time } \\
\text { (months) }\end{array}$} & \multirow{2}{*}{$\begin{array}{c}\text { No of } \\
\text { patients }\end{array}$} & \multicolumn{2}{|c|}{ Mean triglyceride } & \multirow{2}{*}{$\begin{array}{c}\text { Patients } \\
\text { with } \\
\text { reduction }(\%)\end{array}$} \\
\hline & & Baseline & Current & \\
\hline \multicolumn{5}{|l|}{$\begin{array}{c}\text { Before } \omega-3 \\
\text { marine }\end{array}$} \\
\hline triglycerides & 212 & $3 \cdot 76$ & $3 \cdot 76$ & \\
\hline 1 & 207 & 3.76 & $2 \cdot 62$ & $93^{\star \star}$ \\
\hline 3 & 183 & $3 \cdot 72$ & $2 \cdot 33$ & $95^{\star \star}$ \\
\hline 6 & 148 & 3.65 & $2 \cdot 23$ & $94^{\star \star}$ \\
\hline 12 & 125 & 3.61 & $2 \cdot 13$ & $94 \star \star$ \\
\hline 18 & 105 & 3.53 & $2 \cdot 18$ & $91^{\star \star}$ \\
\hline 24 & 91 & 3.60 & $2 \cdot 16$ & $93^{\star \star}$ \\
\hline 30 & 81 & 3.63 & $2 \cdot 11$ & $95 \star \star$ \\
\hline 36 & 71 & 3.68 & $2 \cdot 48$ & $92^{\star \star}$ \\
\hline 42 & 63 & 3.67 & $2 \cdot 34$ & $87^{\star \star \star}$ \\
\hline 48 & 50 & 3.75 & $2 \cdot 43$ & $82^{\star \star}$ \\
\hline
\end{tabular}

$\star \star$ Significant at $0 \cdot 1 \%$ level by binomial test. oil not only lowers triglyceride concentration but also increases fibrinolytic activity. More work needs to be done on the effects of $\omega-3$ fatty acids on the apolipoproteins of high density lipoprotein and very low density lipoprotein and their possible role in fibrinogen reduction and fibrinolysis for it is from this subject that the answer may come.

In conclusion, we think that short term studies of atherosclerosis, which usually takes many years to manifest itself, should be interpreted with caution.

R SAYNOR T GILLOTT

Cardiothoracic Unit,

Northern General Hospital,

Sheffield S5 7AU

1 Saynor R, Verel D, Gillott T. The long term effects of dietary supplementation with fish lipid concentrate on serum lipids, bleeding time, platelets and angina. Atherosclerosis 1984;50: 3-10.

\section{A milestone for myocardial infarction}

I was appreciative of the excellent review and summary of the findings from the second international study on infarct survival (ISIS 2) by Professor D G Julian and Drs B L Pentecost and D A Chamberlain (20-27 August, p 497).

Regrettably, however, they have not fully taken into account a number of factors in their cost benefit analyses which are necessary when introducing a new treatment to the National Health Service. They simplify the conclusions from the ISIS 2 study by highlighting that deaths from vascular disease are reduced from $12 \%$ to $9.2 \%$ with the use of streptokinase. The mortality was similarly reduced to $9 \cdot 4 \%$ among those patient prescribed aspirin and to $8.0 \%$ when both aspirin and streptokinase were used.

The recommendations of the editorial, however, have much wider implications than perhaps its authors realise.

Firstly, it is now essential for all patients after a suspected acute myocardial infarction to be seen by their general practitioner within a few hours or admitted to hospital for assessment. While general practitioners are not encouraged to use streptokinase this will inevitably mean an increased admission rate to hospital, particularly of those with suspected coronaries, where the diagnosis is in doubt. Has the effect of this been quantified and what is the likely increased admission rate to hospital?

Secondly, for treatment to be effective it must be given within the first six hours. Myocardial infarction, however, is a diagnosis made in retrospect, with electrocardiographic changes and altered cardiac enzymes confirming infarction. The diagnosis cannot always be established in the early stages. Are these patients with an unclear diagnosis to be treated as if they did have an infarction? If so there will be a significant number of patients treated who do not have a coronary, thus increasing the overall costs.

Thirdly, when general practitioners are encouraged to use streptokinase in the acute situation (as I am sure will be the logical next step) will they restrict the administration of streptokinase to those with a clinically obvious coronary or, as is more likely, will they use the drug in the majority of suspected cases, thus treating a group who ultimately do not have a coronary?

When quantifying the costs of treatment to the NHS it is essential not only to identify the cost benefit to the individual patient-as has been carried out in the ISIS study - but also to establish the additional or spin off costs, which in this case have not been fully identified. The effect of the editorial will be to increase admission rates to hospital, resulting in a reduction in hospital beds available for other conditions. Until physicians learn to adopt the rules that surgeons have learn over the past 10 years - that is, to make a full and accurate quantification of all the costs of starting a new treatment - there will continue to be controversy about bed management in the National Health Service.

W ANGUS WALLACE

Department of Orthopaedic and Accident Surgery,

Queen's Medical Centre

Nottingham NG7 2UH

\section{Are GP referrals influenced by the availability of consultants?}

It is well known that there are unexplained differences in the rates at which general practitioners make referrals to consultants. ${ }^{1}$ One of the most important aspects of primary care is the general practitioner's need for advice. Dr Martin Roland and $\mathrm{Mr}$ Richard Morris (3 September, p 599) found that the number of outpatients was strongly associated with the provision of consultants in dermatology and three other specialties.

We investigated 5082 referrals from 141 general practitioners to dermatologists in Ringkjøbing county in Denmark ${ }^{2}$ based on data from the national health service. As an expression of the referral rate to dermatologists an index of referra was estimated for every general practitioner. This index was the number of referrals to the dermatologists per 1000 patients per year, including children, standardised for age and sex to the average population in Ringkjøbing county. Six variables were evaluated in relation to the referra index: the distance to the dermatologists, the number of doctors per practice, the number of consultations per general practitioner per year, the number of patients registered, the number of consultations per 1000 patients per year standardised for age and sex, and the number of supplementary procedures per consultation. The study showed that the referral index fell with both the distance to dermatologists and the number of supplementary procedures per consultation. No correlation was found between the referral index and the four other variables studied.

The two studies show that general practitioners adjust their work to the ease of referral to specialists, and from our study doctors with a more extensive use of diagnostic and therapeutic procedures (a high number of supplementary procedures) seem to refer less often to dermatologists.

HENRIK TOFT SØRENSEN BO CHRISTENSEN

CARL ERIK MABECK

Institute of General Practice,

University of Aarhus,

8000 Aarhus,

Denmark

1 Sørensen HT, Christensen B. Referrals from general practice to specialists in Denmark. $7 R$ Coll Gen Pract 1986;36:290-1.

2 Christensen B, Sørensen HT, Mabeck CE. Referral from general practice to a dermatologist. Scand 9 Prim Health Care 1988;6:

\section{Occult AIDS}

Dr M R Hargreaves and others (17 September, p 721) report two cases of AIDS presenting with Pneumocystis carinii pneumonia in elderly patients.

During the past two years we have seen in this department six cases of $P$ carinii pneumonia in patients over the age of 60 . Three of these patients were shown to have AIDS (one homosexual man and two who had had a blood transfusion in 1984). The fourth patient, a bisexual man, had been seropositive for HIV since 1986, and the remaining two had other immunosuppressive disease. In all 